\title{
(RE)THINKING AND (RE)POSITIONING LIBRARY PROGRAMMES AND SERVICES IN PUBLIC HIGH SCHOOLS IN LIMPOPO PROVINCE, SOUTH AFRICA
}

\section{Maredi Samuel Mojapelo}

Department of Information Science

University of South Africa

Pretoria, South Africa

mojapsm@unisa.ac.za

\section{ABSTRACT}

Well-designed and well-planned library school programmes and services are essential to improve the development of reading and information literacy skills, particularly of the learners, which are crucial for the acquisition of life-long learning and independent study and accessing skills. However, because of inadequate and inefficient school library services in most South African schools, teachers and learners are deprived of opportunities to benefit and practically learn library programmes essential for the acquisition of knowledge, skills, competencies, values and orientations. They are also denied fundamental library services due to them. Based on one part of the research project which investigated the resource provision in public high schools in Limpopo province, South Africa, the purpose of this article is to investigate the programmes and services offered by the different library facilities in public high schools in Limpopo province.

\section{UNISA $\cong$}




\begin{abstract}
Although the study took a largely quantitative research design, it was mixed with qualitative data collection methods. Self-administered questionnaires were used to collect quantitative data from the principals or teacher-librarians, while an interview schedule was used to collect qualitative data from the education officials through face-to-face interviews. The findings established that owing to lack of functional libraries in most schools, there are very few schools offering library services and programmes. The study recommends that the national Department of Basic Education (DBE) should ensure that a school library policy with clearly defined library programmes and services is formulated, approved and implemented as a matter of urgency.
\end{abstract}

Keywords: school libraries, school library programmes, high schools, school library services, information literacy skills, Limpopo province, South Africa

\title{
1. INTRODUCTION AND BACKGROUND OF THE STUDY
}

Limpopo is the northernmost province in South Africa. The province is more than 89 per cent rural and, as in most other provinces in South Africa, it is characterised by high rates of poverty because of high rates of unemployment amongst its black inhabitants (Provide 2009; StatsSA 2013). However, the Limpopo provincial government is faced with a host of circumstantial challenges in the provision of rural education to the majority of the schools particularly in socio-economically disadvantaged and marginalised rural communities. In his study, Seroto (2011) outlines the challenges associated with the provision of rural education in historically disadvantaged black schools which were calculatedly under-resourced by the apartheid government before 1994 (Giliomee and Schlemmer 1989). In Limpopo province, the majority of these schools have been declared no or low fee-paying schools and are categorised either in quintiles 1 to 3 because of the poor socio-economic backgrounds of their communities (DBE 2015; Dwane 2010). Subsequently, the vast number of schools in the province are characterised by a dire shortage of classrooms for teaching and learning purposes; insufficient textbooks; lack of decent, standardised, wellresourced, well-staffed libraries; and well-equipped laboratories. Even today (2016), some communities still do not have electricity supply and this restricts opportunities for teachers and learners to use electronic media and equipment to discover knowledge as embodied in the progressive and constructivist teaching and learning styles and approaches (Meier 2005, 88).

The poor road conditions cause a predicament for accessibility in most of the historically disadvantaged communities, particularly during heavy rain obviously restricting expansion of the mobile library and courier services. In her study, Mahwasane (2008) states that unstable and unstandardised bridges in historically disadvantaged rural communities are flooded or washed away when it pours 
heavily. Masoga (2013) confirms that the majority (68\%) of the roads in Limpopo province are gravel roads. Due to telecommunications infrastructural backlogs in the majority of the disadvantaged rural communities, Internet accessibility is a serious challenge. Statistics South Africa (StatsSA 2013) maintains that only 1.8 per cent of the population has access to the Internet in their households in the whole country. It therefore implies that Internet connectivity is still a daunting challenge in this predominantly rural province. With an ineffective and inefficient conventional telephone system, perhaps, despite its flaws, the use of cellular technology may enhance Internet accessibility in historically disadvantaged rural communities.

As in other rural provinces of the country, there are huge inequalities in the distribution of income between the various apartheid racial groupings. The province has the highest level of poverty, with 78.9 per cent of the population living below the national poverty line. StatsSA $(2012,43)$ found that:

Limpopo remained the province with the lowest average annual household income at R56 844, followed by Eastern Cape where the average was R64 539. At the other end of the scale, Gauteng had the highest average annual household income at R156 243 followed by Western Cape with a figure of R143 460 .

The province is some distance away from the economic hub of South Africa Gauteng province, and its wealth lies mainly in its agriculture, plantations, a few mines and game parks. The province is vast and according to StatsSA (2013), its population is 97.1 per cent black.

\section{STATUS QUO OF SCHOOL LIBRARIES IN SOUTH AFRICA}

As in other poor and developing countries in Africa, the status of school libraries in South Africa is depressing. According to the non-governmental organisation (NGO) Equal Education (EE 2011), Hart and Nassimbeni (2013), Hart and Zinn (2015), the Library and Information Services Transformation Charter (DAC and NCLIS 2014) and Paton-Ash and Wilmot (2015), only 7 per cent of the public schools in the country have well-resourced and well-staffed school libraries. This infers that the majority of the learners do not have equitable access to the plethora of library-based resources which are indispensable for inculcating a culture of reading; acquiring information skills; and supporting teaching and learning accomplishments in schools.

To highlight the plight, EE recurrently organised marches throughout the country to sensitise the government about the significance of well-resourced and well-staffed school libraries in the education system in the country. The theme of the campaign was 'one school, one library, one teacher-librarian' (EE 2011; Hart 2014; Hart and Zinn 2015). After a string of court battles with the government, EE's successful struggle with the South African government over the Norms and 
Standards Act was not in vain. The amended South African Schools Act (SASA) (No. 84 of 1996) indicates that 'all schools should have a library facility or media centre facility or library stocks' (DBE 2015, 11). Unfortunately for school library lobbyists, the Act makes no mention of staff and materials in terms of school library provision. However, EE (2011) estimates that more than R12 billion is required from the South African government to provide all public schools with a well-stocked and staffed school library. The amount quoted includes funds for library infrastructure (buildings), library materials, training and employing of a full-time librarian or administrator.

Due to the past apartheid legislation, the education system in South Africa is still characterised by huge disparities and disproportions in resource-provisioning in schools. However, a few historically advantaged ex-Model $\mathrm{C}$ schools in affluent and wealthy communities have well-equipped and well-staffed purpose built central school libraries which are efficiently managed by the professionally qualified librarians, library administrators or library clerks. Unlike their counterparts in historically disadvantaged and marginalised communities, these schools have an annual library budget which is ring-fenced to ensure that pertinent and appropriate educational resources are acquired yearly to meet the curriculum requirements of the teachers and learners. In these schools, parents pay extra fees for the procurement of the additional educational resources. Learners in these schools therefore have a better chance to develop and acquire an assortment of skills which are indispensable in today's information and knowledge-based society. Hart $(2014,3)$ notes that:

Today's library provision retains the inequities of apartheid education. The vast majority of South African school libraries and school librarians exist within schools serving middle class communities, who are able to levy fees and raise funds for 'extra' resources and teachers 'extra' to the learner/teacher ratios set by the Department of Basic Education (DBE).

Hart $(2013,49)$ also reaffirms that:

Few exist: fewer than ten percent of schools have functioning libraries with an annual budget and a staff member. The few comprise the historically advantaged, so-called ex-Model C suburban schools, which are able to supplement their government budgets by levying fees from their largely middle-class parent bodies.

Due to their sound financial footing, historically advantaged ex-Model C schools therefore have the capacity to utilise their library and information-based resources to successfully implement well-planned and well-articulated library programmes and services to fully support the constructivist, progressive and innovative teaching and learning platforms as embodied in the learner-centred education system. Learners in these schools therefore have high prospects to become lifelong and independent readers because they are exposed to well-resourced and well-managed libraries to optimally develop, promote and nurture their reading habits, skills and culture. Ex-Model C schools therefore have the potential to attract more learners from the 
historically disadvantaged rural communities, informal settlements and townships. According to Hart (ibid., 58-59), 'The historically 'white' 'advantaged' suburban and inner-city schools have more diverse student bodies, as their superior facilities attract many township residents.'

Ex-Model C schools perform better academically compared to their counterparts in socio-economically disadvantaged rural communities. As they interact and access a wide variety of reading materials in different languages, learners' reading skills and habits are honed. The more they read, they better they will perform. Pretorius and Machet $(2008,262)$ state that: 'Research findings consistently show a strong relation between literacy (specifically reading ability) and academic success, from primary school right through to tertiary level.'

The significance of an adequate and diverse collection in boosting the performance of the learners in such schools cannot be overemphasised (EE 2011). It should be noted that these schools were designated for non-blacks during the apartheid era. The Bantu Act (No. 47 of 1953) disempowered black learners educationally. The apartheid government state funding was therefore discriminatory (Giliomee and Schlemmer 1989; Kalley 2000). Kalley $(2000,1)$ states that 'the deep schism in literacy levels was further exacerbated by the introduction of the Bantu Education Act, which transferred the control of black education from provincial to central control'. Aitchison $(2006,96)$ confirms that: 'The funding of schools was organised in such a way as to keep black schools under-resourced. In addition, schools in rural areas would be even more likely to be under-resourced than those in urban areas and many still are.'

Due to the poor socio-economic conditions of blacks who were confined to homelands in historically disadvantaged rural communities during the apartheid era, their schools were built without well-resourced and staffed school libraries and wellequipped laboratories. The National Library of South Africa $(2015,21)$ confirms that:

Before 1994, schools were divided according to race. White schools were provided with libraries and teacher-librarians. Black secondary schools that fell under the South African government had libraries but no library staff, while some black primary schools had classroom collections. Schools in the so-called homelands had no library provision whatsoever.

The Reservation of Separate Amenities Act (No. 49 of 1953) legalised provision for separate buildings and services for the different race groups (blacks, whites, coloureds and Indians) in apartheid South Africa (Kalley 2000) and also outlawed learners of the different race groups from schooling together. Worden $(2000,108)$ states that:

The Reservation of Separate Amenities Act (1953) enforced social segregation in all public amenities, such as transport, cinemas, restaurants and sports facilities. And educational apartheid was enforced in schools (1953), technical colleges (1955) and universities (1959). 
African schooling was still neither free nor compulsory as it was for whites. Certainly, educational provision for Africans before this period had been unequal and most government schools separated white and African pupils.

The apartheid government persistently injected more funds into the white schools to make them better resourced than their black counterparts (Giliomee and Schlemmer 1989). Hart and Zinn $(2007,90)$ confirm that: 'In 1994, per capita expenditure varied between R5403 on 'white schools' and R1053 on schools in the Transkei homeland. Repetition and pass rates correlated closely with these differences'.

The aim of this unequal expenditure in schools was to equip white schools properly and to give white learners superior education at the expense of their black counterparts. Even at the time of writing (2016), schools designated for blacks under the apartheid rule are still under-resourced. Due to huge shortages of classrooms for teaching and learning, mud schools are still noticeable in some provinces such as the Eastern Cape. Due to dilapidation and infrastructural backlogs in terms of the provision of classrooms, mobile classrooms are evident in historically disadvantaged and marginalised rural communities of Limpopo, Eastern Cape and KwaZulu-Natal (Motseke 2005). The Bantu Education Act enforced racially separated educational amenities. Teachers and learners in those historically disadvantaged communities still feel the brunt. School libraries are still regarded as 'luxuries' because the Limpopo provincial government must still tackle classroom shortages head-on in most communities throughout the province. It seems impossible therefore to implement library programmes and services in the majority of the schools with dysfunctional library and information services. Because the province is made up of three former homelands which had been designated specifically for blacks under the notorious Group Areas Act (No. 41 of 1950), the majority of the schools in these communities do not have well-resourced and well-staffed school libraries (Giliomee and Schlemmer 1989). According to the National Infrastructure Education Management System (NEIMS 2011), only 2.3 per cent of the public schools in Limpopo province have well-resourced and well-staffed school libraries. Moreover, only 10 per cent of the population have access to the library and information resources in public or community libraries (Limpopo. DSAC 2009). In his broader study on the provision of school libraries in public high schools in Limpopo province, the researcher sought to find out whether or not the surveyed schools had a library facility. Table 1 depicts the findings of the study. 
Table 1: Existence of a library facility in schools

\begin{tabular}{|l|l|l|l|l|l|}
\hline \multicolumn{2}{|l|}{ Rural schools } & Frequency & $\%$ & Valid \% & Cumulative \% \\
\hline \multirow{3}{*}{ Valid } & Yes & 32 & 27.1 & 27.1 & 27.1 \\
\cline { 2 - 6 } & No & 86 & 72.9 & 72.9 & 100.0 \\
\cline { 2 - 6 } & Total & 118 & 100.0 & 100.0 & \\
\hline Urban schools & Frequency & $\%$ & Valid \% & Cumulative \% \\
\hline Valid & Yes & 22 & 48.9 & 48.9 & 48.9 \\
\hline & No & 23 & 51.1 & 51.1 & 100.0 \\
\hline & Total & 45 & 100.0 & 100.0 & \\
\hline
\end{tabular}

Source: Mojapelo 2014

The findings distinctly indicate a dramatic shortage of library facilities in historically disadvantaged rural communities; however, it is clear that schools in the urban schools category are better off (Mojapelo 2014). It should be made clear that black schools in townships are in urban communities although they were disadvantaged by the apartheid education system prior to 1994.

The study also established that schools use different library facilities to accommodate the few available library resources (Mojapelo 2014). Table 2 indicates the library facilities used by schools:

Table 2: $\quad$ Types of school library facilities used $(N=157)$

\begin{tabular}{|l|c|c|l|l|l|l|}
\hline $\begin{array}{l}\text { Types of school } \\
\text { library facilities }\end{array}$ & $\begin{array}{l}\text { Number } \\
\text { of rural } \\
\text { schools }\end{array}$ & $\%$ & $\begin{array}{l}\text { Number } \\
\text { of urban } \\
\text { schools }\end{array}$ & $\%$ & $\begin{array}{l}\text { Cumulative } \\
\text { totals }\end{array}$ & $\begin{array}{l}\text { Cumulative } \\
\%\end{array}$ \\
\hline $\begin{array}{l}\text { Staffroom or } \\
\text { administrative office } \\
\text { converted into a } \\
\text { library }\end{array}$ & 39 & 34 & 10 & 23 & 49 & 31 \\
\hline $\begin{array}{l}\text { Classrooms (central) } \\
\text { converted into school } \\
\text { libraries }\end{array}$ & 27 & 24 & 10 & 23 & 37 & 23 \\
\hline $\begin{array}{l}\text { Purpose-built } \\
\text { (central) library }\end{array}$ & 17 & 15 & 15 & 34 & 32 & 20 \\
\hline Storeroom & 23 & 20 & 7 & 16 & 30 & 19 \\
\hline $\begin{array}{l}\text { Collections of books } \\
\text { kept in boxes in } \\
\text { classrooms }\end{array}$ & 8 & 7 & 1 & 2 & 9 & 6 \\
\hline $\begin{array}{l}\text { Total number of } \\
\text { respondents }\end{array}$ & 114 & $\mathbf{1 0 0}$ & $\mathbf{4 3}$ & 100 & 157 & 100 \\
\hline
\end{tabular}

Source: Mojapelo 2014 
From Table 2, it is clear that most schools, particularly in the historically disadvantaged rural communities, were built without standardised purpose-built libraries. Six respondents, four from rural and two from urban schools, did not reply. The study also revealed that owing to lack of funding, library facilities have a lot of 'unsuitable materials' which offer little curriculum support (Mojapelo 2014). Lack of staff in most schools is a daunting challenge affecting the functionality of library facilities. Out of 163 respondents, only seven (4\%) indicated that their schools have a full-time teacher-librarian. Historically advantaged ex-Model C schools have fulltime teacher-librarians to manage library resources centrally. This implies that most of the library facilities are locked most of the time due to lack of staff to run and manage them. When asked whether or not teachers and learners have access to the library resources, no respondent in the study indicated that there is a library period to access and utilise available resources (ibid.).

\section{AIM OF THE STUDY}

Given a documented dramatic shortage of well-resourced and well-staffed school libraries in South African schools, learners' literacy levels are low because they lack exposure to wide-ranging information materials. Consequently, South African learners are performing dismally in international and local standardised tests. Out of 40 countries, South African learners came last in the Progress in Reading Literacy Study (PIRLS) in 2006 and 2011. Locally, learners fare badly in the Annual National Assessments (ANA) which test literacy levels and proficiencies particularly in numeracy, languages and science (Mojapelo 2014; Silbert and Bitso 2015). With this backdrop, the aim of the study was twofold:

- Firstly, to identify library programmes and services in public high schools in Limpopo province.

- Secondly, to determine the extent to which identified library programmes and services are offered in state schools; and the role of the Limpopo Department of Basic Education (School library Unit) in library programmes and services.

However, it was not the intention of the study to determine the literacy levels of the learners in the surveyed schools.

\section{SCHOOL LIBRARY POLICIES IN DEVELOPING COUNTRIES}

In South Africa, as in most developing African countries, it is a major challenge to offer well-planned library programmes and services to the majority of the schools particularly in historically disadvantaged communities. Most researchers, such as Du Toit and Stilwell (2012) and Hart (2013), highlight the importance of 
an approved and legislated school library policy in championing the rolling-out of active, dynamic and sustainable library services for all schools in the country. Library and Information Services (LIS) professionals and commentators observe a lack of political will in most African governments to take seriously the provision of decent, standardised, well-resourced and well-staffed school libraries. A lack of authorised and legislated school library policies in most developing African countries is a testimony to this. Ocholla (2009) reiterates that governments, particularly in poor and developing countries, are hesitant to pledge themselves to roll out effective, efficient and sustainable library services for their schools. Without a legislated and authorised school library policy, however, the government lacks essential documents which will provide effective guidance and direction concerning the establishment, development and sustainability of well-resourced and staffed school libraries.

In South Africa, the lack of an approved and legislated school library policy remains a stumbling block for the provision of an active and vibrant school library service and effective implementation of the clearly spelt-out and well-designed library services and programmes. Since 1997, various drafts of school library policies have been produced by the DBE. However, as yet, there has been no legislated school library policy from the DBE in Pretoria. The dissolution and eventual closure of the School Library Unit in 2005 speaks volumes (Hart 2014, 4). This is a crystal clear indication that functional school libraries are not yet prioritised under the new political dispensation in South Africa.

\section{CURRICULUM CHANGES SINCE 1994: IMPLICATIONS FOR SCHOOL LIBRARIES}

Since the dawn of the new political dispensation in 1994, school library lobbyists have been positive that the new government would take school libraries seriously in order to uplift the quality of education for all learners irrespective of race, gender or creed. However, even today (2016), nothing much has changed. In historically disadvantaged rural schools, the situation appears to be even worse.

The introduction of Outcomes-Based Education (OBE) in January 1998 gave school library lobbyists another hope that the new government would earnestly roll out effective, well-resourced and staffed library services for all schools in South Africa (Mojapelo and Fourie 2014). As OBE was a learner-centred and resourcebased methodology of teaching and learning, a diverse range of library-based resources were essential for its successful implementation (Hart 2014). The OBE curriculum was phased out in 2011/12 because it proved to be a challenge for teachers and learners, particularly in historically disadvantaged rural communities, townships

and informal settlements, to implement it successfully without the adequate use of library-based resources in schools (Motseke 2005). 
The new curriculum, Curriculum Assessment and Policy Statements (CAPS) was introduced in 2011/12 to replace OBE (DBE 2011; Mojapelo and Fourie 2014). According to Mojapelo and Fourie $(2014,126)$, 'the emphasis is on the selection of quality learner and teacher support materials (LTSM) to implement the curriculum'. CAPS as a policy document mentions nothing about school libraries.

However, the National Guidelines for School Library and Information Services (DBE 2012) is the latest document produced by the DBE to guide and steer schools in the establishment and provision of functional school libraries to support resourcebased teaching and learning as required by the resource-based curriculum in South Africa. The National Guidelines for School Library and Information Services (DBE 2012, 3) state that: 'The vision of the DBE is that of schools having well-resourced and functioning school library and information services which will contribute towards ensuring that all learners and teachers are information literate and independent lifelong library users and readers.'

The document emphasises the use of a wide variety of resources to support the curriculum. The emphasis is on the schools to select, adopt and implement appropriate and effective school library models to promote equitable access to a wide range of educational resources by teachers and learners. Chapter three of the National Guidelines for School Library and Information Services (DBE 2012) explicitly outlines the advantages and disadvantages of each of the five proposed school library models. The aim is for schools through their School Governing Bodies and School Management Teams to make informed decisions and to select apposite school library models appropriately. However, it should be noted that the National Guidelines for School Library and Information Services (DBE 2012) is not an approved and legislated school library policy. It is a mere guideline as echoed by Hart (2013). This means that destitute and poor schools that do not have the sufficient funds to use the information and implement the ideas in the National Guidelines for School Library and Information Services (DBE 2012) will be unable to implement many of the guidelines.

\section{DEFINITIONS OF TERMS}

The following terms are defined because they are considered relevant for the study:

\subsection{Progressive education paradigm}

Progressive education, also known as progressivism, is an education paradigm or strand where the emphasis is on active-based education or learning by doing (Meier 2005, 77). The American John Dewey (1859-1952) was the founder of this strand of education (Gutek 1972, 382). Like OBE, progressive education is a learner-centred approach to teaching and learning. According to Guthrie (2013, 
122), 'the progressive view is that the student is the centre of the classroom rather than the teacher, and knowledge is to be discovered, not transmitted'. In progressive classrooms, 'development of the enquiring mind needs enquiry teaching methods in schools' for learners in particular to discover, construct and generate knowledge (ibid., 121).

Unlike the traditional (old) or formalistic education paradigm which is teachercentred, in progressive education, team approach or collaborative learning is encouraged for learners to work together to discover new knowledge. Progressive education therefore 'includes more active and participatory learning methods' as learners do not receive released knowledge but need to discover new one (Meier $2005,76)$. For learners in particular to discover embedded knowledge, a wide-variety of information sources in various formats is critical. For a country to successfully implement the progressive education, the pivotal role of the well-resourced and functional libraries, well equipped laboratories, and sport grounds in all schools is critical for learners in particular to discover knowledge. However, Guthrie (2011) warns that progressive education methods are not successfully implemented in developing countries due to lack of adequate resource-provision in schools. Wellequipped libraries and laboratories are essential to stimulate learners' imagination to think critically to discover knowledge.

\subsection{Homelands or bantustans}

During the apartheid era in South Africa (1948-1994), the country was distinctly divided into white and black areas. In line with the apartheid ideology of the separation of cultures, homelands were created to keep blacks away from whites and their communities (Giliomee and Schlemmer 1989). Homelands were blacks only reserves established by the apartheid government to keep them [blacks] out of the white South Africa. Influx control measures were tightened to bar blacks from invading and intruding into the white communities (Worden 2000, 124). Various Acts were promulgated in the parliament to propel and perpetuate philosophy or ideology of the apartheid (separation). Through the homeland system, blacks were permanently removed from white South Africa and confined to the poor, overcrowded and jobless bantustans where the quality of life was poor and miserable. To drive the divide and rule apartheid ethos, blacks were not seen as one single race, but as different ethnic groups, such as Sothos, Zulus, Xhosas, Vendas, Tsonga-Shangaans, Ndebeles, Swazis and Tswanas (Giliomee and Schlemmer 1989; Worden 2000). However, whites were regarded by the apartheid government as one single major race or group outnumbering each and every black ethnic group in South Africa so that they could rule the country. Despite living in ghettoes and their contextual squalor conditions, blacks residing in homelands also lost their rights they were entitled to in 
South Africa. Their political rights were confined to their homelands or bantustans. Worden $(2000,124)$ asserts that:

The 1959 Promotion of Bantu Self-government Act set up eight (later extended to ten) distinct 'Bantu Homelands' out of the existing reserves, each with a degree of self-government. Not only did this greatly extend the powers of co-opted local chiefs, but it established the principle of ethnicity as basis of the homelands. Africans were divided into distinct 'nations' based on their historic homelands. Ethnic homeland loyalty was to replace national political aspirations in a move which the state hoped would defuse calls for the moral necessity of African self-government within South Africa itself.

Ethnicity and languages were the pillars and cornerstones used for the creation of the homelands or bantustans in apartheid South Africa. There were independent states and self-governing territories. Independent states (in brackets is the year nominal independence was given) included: Transkei (1976), Bophuthatswana (1977), Venda (1979) and Ciskei (1981). Transkei and Ciskei were homes to Xhosa speaking groups, while Bophuthatswana and Venda were homes to Setswana and Tshivenda speaking groups, respectively. Self-governing territories included Lebowa for Sesotho sa Leboa speaking groups, Gazankulu for Tsonga-Shangaan speaking groups and Kwandebele for Ndebele speaking groups. Kwangwane was home to Siswati speaking groups, while KwaZulu and Qwaqwa were homes to Isizulu and Sesotho sa Borwa speaking groups. The homeland system prior to 1994 caused the majority of blacks to cluster in homelands where poverty and illiteracy levels were high. Under the bantu education system, black schools were under-funded, underresourced and had poorly qualified teachers to offer black children poor and inferior quality education. South African blacks were even more fragmented and divided during the homeland system during the apartheid era in South Africa (ibid., 124).

\subsection{Ex-Model C schools}

In South Africa, ex-Model C schools are public schools in historically advantaged affluent communities which were reserved or earmarked for whites only learners during the apartheid era (Bloch 2009; Roodt 2011). These are historically advantaged and privileged schools with the best teachers, best education resources and best libraries, laboratories, sport grounds or fields (Hart and Zinn 2015). These are also schools which provide learners with the best educational opportunities. Despite the government subsidy, these schools are permitted to top up or supplement their state allocation (funds) and therefore their learners pay extra fees for the procurement of extra resources including information-based resources (Collinridge 2013). In addition, also through fundraising, these schools have the financial muscle to employ extra teachers to distribute workloads evenly. Ex-Model C schools are characterised by the excellent performance of their learners and Bloch $(2009,129)$ dubs them the 'jewels of the excellence in the school system' in South Africa. Since the inauguration 
of the new democratic government in 1994, these schools have experienced a high influx of black learners from the disadvantaged rural communities, townships and informal settlements.

\subsection{Quintile system}

For funding purposes, all public schools in South Africa have been categorised into five groups or quintiles. Collingridge $(2013,2)$ states that: 'For the last 17 years, all public schools in South Africa have been funded according to the category they have been allocated by the national Department of Education.'

The socio-economic conditions of communities in which schools are located are used to rank or classify them. According to Hall and Giese (2008/2009, 37):

The national poverty table, prepared by the Treasury, determines the poverty ranking of areas based on data from the national census including income levels, dependency ratios and literacy rates in the area. Provinces then rank schools from quintile 1 to 5, according to the catchment area of the school. The poorest schools are included in quintile 1 and the least poor in quintile 5 .

To ensure free, affordable and accessible compulsory education for learners in poor rural communities in South Africa, schools in quintiles 1 to 3 are no fee-paying schools. This implies that learners in these schools are exempted from paying school fees (DBE 2013). According to Collinridge (2013, 3):

These are schools where learners got a much bigger subsidy from the government (of R1 010 this year) compared to learners in quintile 4 schools who got an average half of that (R505 this year) and learners in quintile 5 who got roughly only $10 \%$ of that (R174 this year). Quintile 4 and 5 schools were expected to supplement their state allocation through the charging of school fees and fundraising.

\subsection{Teacher-librarians}

Teacher-librarians are responsible for the day-to-day activities of the school library. They carry out the managerial functions of planning, organising, staffing, directing and controlling, with the assistance of the school library committee. They are also responsible for accessioning, cataloguing and classifying library materials (Mojapelo 2014) and for the issuing and returning of library resources to and from the users. According to the National Guidelines for School Library and Information Services (DBE 2012, 38), the term 'teacher-librarian' is:

A generic term for the various names used in schools for educators who manage the library and information resource facilities and collections, and who collaborate with teachers in promoting reading, as well as in the teaching and integration of information literacy skills 
into the curriculum, such as librarians, media teachers, media specialists, media centre teachers, resource centre teachers and information specialists.

The teacher-librarian is supposed to have both teaching and LIS qualifications to manage and run the school library effectively. The word 'teacher-librarian' is used in the current study for someone who is responsible for, and in charge of, the library and its resources and who may not be professionally qualified. In South Africa, due to the serious lack of specialist librarian posts in schools, the so-called teacher-librarians are working in school libraries part-time as they also have full-time teaching responsibilities in classrooms (Mojapelo 2014). They are allocated the same number of periods as the other teachers in the school system and this leads to them neglecting their duties as teacher-librarians. Interested so-called teacher-librarians run libraries by using their few free periods a week (DAC and NCLIS 2014).

\section{RESEARCH METHODOLOGY}

As already alluded to, this article is part of a larger study which investigated the provision of school libraries in public high schools in Limpopo province, South Africa. Although the study had elements of qualitative research because all three education officials attached to the School Library Unit in Polokwane were interviewed, the quantitative study design (survey) was mainly or largely adopted. Self-administered questionnaires were used to collect data from the principals or teacher-librarians. For the current article, the research questions for principals or teacher-librarians were:

- Which library programmes and services are offered in schools?

- To what the extent are identified library programmes and services offered in schools?

For education officials, the research questions were formulated as follows:

- Which library programmes and services are offered to the teachers and learners by the Limpopo Department of Basic Education?

- Does the Department of Education support the celebration of Readathon or Literacy Month?

According to the Limpopo Department of Basic Education's Annual Survey Update Master (Limpopo. DBE 2015), there are 1428 registered public high schools which are scattered in all five districts of the province. To obtain a sample size relative to the size of the wider population under study, 'a look-up table for sample sizes 
from different sized universes' was used (Payne and Payne 2004, 204). According to Payne and Payne (ibid.), if the target population comprises 1500 units of analysis, then the sample should be 306 . As the target population in this study was 1428 state high schools, a total of 306 public high schools in the province was targeted.

Within the sampled schools, the study specifically targeted principals or teacherlibrarians. As schools are located either in rural or urban communities, it was necessary to categorise them in the study to ensure an inclusive and representative sample. Two sampling methods were used, namely, stratified and systematic random sampling. Firstly, a stratified sampling technique was applied (Keyton 2011). Two lists of schools were created - a rural and an urban school list. The aim was to draw state high schools from various socio-economic backgrounds to ensure an even spread of schools in both strata in a sample. Secondly, a systematic random sampling technique was applied to both rural and urban school sampling frames to ensure fair distribution and selection of schools in each stratum (Walliman 2011). From the list of $1265(89 \%)$ rural schools, 254 schools were chosen randomly. From a total of $163(11 \%)$ urban schools, 52 schools were selected randomly. Self-administered questionnaires with self-addressed envelopes were mailed to the 306 principals or teacher-librarians. There was a response rate of 163 schools, 118 rural schools and 45 urban schools.

Other respondents in the study included three education officials, two chief education specialists and a senior manager all attached to the School Library Unit of the Limpopo DBE in Polokwane. Due to the virtue of their appointments, they were all selected through purposive sampling. They are employed and paid by the Limpopo DBE and their main function is to assist schools to set up functional libraries in the province. They are supposed to run workshops related to school libraries. They are also supposed to visit and monitor library facilities and resources at schools. An interview schedule was used to conduct face-to-face interviews to obtain qualitative data from them.

\section{PRESENTATION AND DISCUSSION OF FINDINGS}

The study sought to identify the library programmes and services offered by the various library facilities in the schools. On the self-administered questionnaires, lists of school library programmes and services were provided and respondents were requested to tick applicable block(s). Space was also provided for 'other' types of library programmes and services not listed on the questionnaires. The findings are indicated in Table 3: 
Table 3: Programmes and services offered by school library facilities $(N=163)$

\begin{tabular}{|c|c|c|c|c|c|c|c|c|}
\hline $\begin{array}{l}\text { Library } \\
\text { programmes } \\
\text { and services }\end{array}$ & $\begin{array}{l}\text { Number } \\
\text { of rural } \\
\text { schools }\end{array}$ & $\%$ & $\begin{array}{l}\text { Number } \\
\text { of } \\
\text { urban } \\
\text { schools }\end{array}$ & $\%$ & $\begin{array}{l}\text { Cumulative } \\
\text { totals }\end{array}$ & $\begin{array}{l}\text { Cumulative } \\
\%\end{array}$ & $\begin{array}{l}\text { Cumulative } \\
\text { totals of } \\
\text { schools } \\
\text { which } \\
\text { did not } \\
\text { respond } \\
\end{array}$ & $\%$ \\
\hline $\begin{array}{|ll|}\text { 1. } & \text { Reading } \\
& \text { programmes }\end{array}$ & 14 & 12 & 4 & 9 & 18 & 11 & 145 & 89 \\
\hline $\begin{array}{|ll|}2 . & \text { Information } \\
& \text { literacy } \\
& \text { skills and } \\
& \text { programmes } \\
\end{array}$ & 2 & 2 & 3 & 7 & 5 & 3 & 158 & 97 \\
\hline \begin{tabular}{|ll} 
3. & Marketing \\
of library \\
activities
\end{tabular} & 1 & 1 & 1 & 2 & 2 & 1 & 161 & 99 \\
\hline $\begin{array}{|ll|}\text { 4. } & \text { Library } \\
& \text { programmes } \\
\end{array}$ & 1 & 1 & 2 & 4 & 3 & 2 & 160 & 98 \\
\hline $\begin{array}{|ll|}5 . & \text { Outreach } \\
& \text { programmes } \\
\text { and } \\
\text { competitions }\end{array}$ & 4 & 3 & 0 & 0 & 4 & 2 & 159 & 98 \\
\hline \begin{tabular}{|l}
6. \\
$\begin{array}{l}\text { Celebrations } \\
\text { of library } \\
\text { calendar } \\
\text { days }\end{array}$
\end{tabular} & 5 & 4 & 4 & 9 & 9 & 6 & 154 & 94 \\
\hline $\begin{array}{l}\text { Number of } \\
\text { respondents }\end{array}$ & 118 & 100 & 45 & 100 & 163 & 100 & 163 & 100 \\
\hline
\end{tabular}

\subsection{Reading programmes}

From Table 3, out of 163 , close to one eighth (11\%) of the respondents collectively indicated that they had reading programmes at their schools. This implies that there are no reading programmes in the vast majority of the public schools in Limpopo province to motivate learners specifically to acquire, improve and inculcate reading habits, skills and culture. This coincides with inadequate and dysfunctional library services in most of the schools in the province. This partly explains why South African learners are performing badly in the acquisition of literacy and numeracy skills because the majority of them are not exposed to reading and reading programmes at schools. In schools in historically disadvantaged rural communities, the situation can even be worse as most parents are poor and therefore lack money to secure books for voluntary or leisure reading (Machet and Tiemensma 2009). Jansen (2013 quoted by Hart 2014, 3) describes 'our literacy levels as a "national disaster". Chapters 5 and 8 of the IFLA/UNESCO (2015) School Library Guidelines and the National 
Guidelines for School Library and Information Services (DBE 2012), respectively, outline various programmes and activities which schools are supposed and expected to implement to promote the acquisition of various literacies for the benefit of the learners. Having few public or community libraries in historically disadvantaged communities of the Limpopo province restricts learners from attending story telling sessions which have a potential to stimulate them to read (DAC 2013). Tiemensma $(2008,84)$ confirms that:

In developing countries like South Africa, voluntary reading is often restricted by the limited number of libraries. Under the previous system of apartheid, library provision in South Africa in the black townships, informal settlements and rural communities was less favourable than that for white urban areas. Public libraries are still mainly serving the educated and urban middle class, which is a small minority (less than 10\%) of the population.

The conditional grant by the Department of Arts and Culture (DAC) to establish more community-based libraries particularly in historically disadvantaged rural communities is a right step in the right direction for poor people living in such communities to access information for personal growth and development. However, the rolling-out of such amenities is moving at a snail's pace due to some officials who lack the capacity to fully utilise the conditional grants (Bodlani 2015).

It is incontestable that the virtual non-existence of well-resourced and wellstaffed libraries in the majority of the schools in South Africa has devastating consequences in the acquisition of reading literacies of the learners. It is therefore extremely difficult for learners to develop and acquire the reading skills, habits and culture without being exposed to diverse library and information-based resources. As observed by Chizwina (2011, 228), when learners are not exposed to multimedia resources such as books including talking books, it is difficult for learners to develop 'basic reading skills required for learning. It is also difficult for learners to develop minimum levels of mastery in reading, decoding and comprehension skills' (ibid.). A few well-stocked and functional school libraries in South Africa as observed by Chizwina (ibid.) implies that the 'interaction between the book and the reader is absent'. This makes reviving a reading culture and inculcation of reading skills and habits a nightmare which is currently the case with South African learners. This also partly explains why South African learners perform badly in the ANA, specifically in terms of writing, numeracy and reading (DBE 2013, 2014). This is affirmed by the PIRLS results of 2006 and 2011 where learners from South Africa came last out of 40 countries which took part in the study. Hart $(2013,50)$ confirms that:

South African children came last in the Progress in Reading Literacy Study (PIRLS) study in 2006, which tested primary school leavers' reading in their home language in 40 countries. The PIRLS survey suggests that the lack of access to libraries in South Africa may partly explain this poor performance. Internationally, 89 per cent of high-scoring respondents in the PIRLS survey attended schools with libraries and 69 per cent had access to classroom 
reading collections. Fifty per cent were taking books home from their classroom collection every day, while an equal percentage visited the central school library at least once a week.

By spending time in the library reading, learners acquire reading skills, learning habits and reading culture (Zinn 2006). Adeoti-Adekeye $(1997,586)$ contends that learners should be taught those skills that will make their use of the library both fulfilling and rewarding and also to cultivate in them a reading habit for independent and life-long learning. Without doubt, school libraries are therefore ideal centres where teacher-librarians can cultivate the culture of reading in learners. Tiemensma $(2006,13)$ asserts that:

Reading is an essential competency in the 21 st century. The school plays the most important role in the acquisition of the technical skills of reading and writing. Literacy learning is considered to be the most essential skill to be gained and one of the prime areas of importance in the primary school. Teachers and schools are expected to take responsibility for making learners literate.

This implies that different library-based resources in different formats which are responsive to the acquisition of reading skills specifically by learners are essential to instil reading habits and culture. The significance of well-resourced and well-staffed school libraries with well-planned reading programmes cannot be overemphasised. However, in their study, Magara and Batambuze (2009) contend that reading should be promoted in schools to stimulate learners to develop and acquire reading skills, habits and culture from primary school education. In the current study, there is no significant difference between urban and rural schools in terms of reading programmes. When asked which programmes the DBE offers, the education officials replied as follows:

Education official A: We are encouraging teacher-librarians to motivate learners to read, however, there are no tailored reading programmes related to libraries including school libraries.

Education official B: During the few workshops we had, teacher-librarians were encouraged to motivate learners to read.

Education official C: Reading is important for learners to acquire reading skills. Without budget, we are not able to organise reading competitions for learners in different schools to take part. However, we encourage schools to celebrate Readathon in September. Due to lack of budget we cannot organise anything.

The Library and Information Services Transformation Charter (DAC and NCLIS 2014, 48) avows that:

School libraries develop the reading literacy crucial for academic achievement and participation in a democracy. Teachers might teach children how to read but everyday access to attractive books in their home languages leads children to enjoy reading. The more they enjoy reading, the more they will read - and the better they will read. Internationally, reading 
ability has been shown to be a critical factor in academic performance and in keeping learners at school.

The National Guidelines for School Library and Information Services (DBE 2012, 31) stipulate that the school principal has a responsibility to ensure that:

Every learner learns to read;

Steps are taken to promote reading;

Reading strategies are integrated in all school subjects; and

A culture of reading is instilled in the school.

In order to support the above, the principal should ensure that the School Library Committee develops an annual literacy programme that promotes reading for the sake of enjoyment.

However, these good intentions remain futile without a well-stocked and wellstaffed school library in each school and active school library committees. In their study, Mojapelo and Dube $(2014,8)$ indicate that the majority $(76 \%)$ of the schools in Limpopo province operate without a school library committee.

\subsection{Information literacy skills and programmes}

Out of 163 , only five (3\%) respondents cumulatively indicated that they have information literacy skills and programmes at their schools. This is the reason a majority of the teachers and learners in most schools lack such skills. According to the National Guidelines for School Library and Information Services (ibid., 30), information literacy skills can be categorised into two groups:

- The first category comprises skills that are instrumental in involving the utilisation of the school library, such as locating and collecting information. These are merely basic library skills, such as information retrieval skills or knowing how library material is classified and catalogued, or how to find information in the library.

- The second category comprises skills that are cognitive in nature, such as analysing, synthesising, creating, evaluating and presenting. Such skills go beyond finding information to how information could be effectively utilised. It takes into consideration issues pertaining to the ethical use of information, the verification of information, as well as reaching the highest level of information usage in order to solve problems, provide original solutions and generate knowledge.

With well-resourced and functional school libraries, teachers and learners can acquire information literacy skills to make them information literate citizens who will be able to locate, find, analyse, evaluate and use information critically on a daily basis. The acquisition of information literacy skills to use information and 
communications technologies (ICTs) by teachers and learners to access global information cannot be over-emphasised in this digital era. With well-designed and implemented information literacy skills in a school library setting, cognitive skills of the learners are expected to improve drastically. With a school library staffed with a dedicated, qualified and knowledgeable librarian, learners and teachers can be taught how to analyse, synthesise, evaluate and present retrieved information to accomplish their curriculum-related accomplishments. According to the National Guidelines for School Library and Information Services (ibid., 29): 'Building a culture of responsibility and humanity in our schools is highly applicable in the information age and information society where teachers and learners are characterised by effective acquisition of information literacy skills essential for retrieval of information.'

Ideally, it is the responsibility of the teacher-librarians to ensure that teachers and learners use library and information-based resources maximally to support effective teaching and learning initiatives. To ensure this, teachers and learners should acquire the necessary information literacy skills to ensure maximum utilisation of resources including e-resources to enhance and improve the quality of education in schools. Adeoti-Adekeye $(1997,586)$ reiterates that 'the correct and successful use of library materials forms the basis of effective learning in schools'. Therefore, users of school libraries in general, and learners in particular, should be given adequate training and guidance on how to maximise the use of library and information resources to meet their curricular and non-curricular needs. The acquisition of basic information literacy skills therefore becomes crucially important for both teachers and users. Teacher-librarians are expected to develop a programme to teach information literacy skills to users to enable them to source materials on their own to support the constructivist and inquiry classroom-based activities (Zinn 2006). The IFLA/ UNESCO School Library Guidelines $(2015,73)$ reiterate that 'curriculum and integration' of information literacy skills is indispensable to sharpen and hone the accessing and mental skills of the learners. When asked whether or not learners learn information literacy skills and programmes, education officials responded as follows:

Education official A: Learning information literacy skills is critical for learners, however, due to lack of manpower, very few schools provide such programmes.

Education official B: They are extremely important for learners to acquire, but most schools do not offer such programmes.

Education official C: Teacher-librarians have heavy teaching workloads. They therefore lack time for teaching such programmes. Full-time-teacher-librarians are needed specifically to teach such programmes. 


\subsection{Marketing of library facilities}

Teacher-librarians are responsible for the marketing of the library facilities, services and resources (collection) to make users aware of them. They can organise displays and exhibitions to market services and resources in the libraries (DBE 2012). The aim is to draw the attention of the users to inform them that there are new resources they can use to satisfy their information needs. In this study, out of 163 , two (1\%) of the respondents indicated that they marketed library facilities. The National Guidelines for School Library and Information Services (ibid., 29) confirm that:

The School library and Information services provided by the school library must be actively promoted so that the target groups are always aware of the library's essential role as a partner in learning and teaching and as a gateway to all kinds of information sources.

Although they recognise the importance of marketing of the library services, all the education officials indicated that unfortunately it is not happening in most schools.

\subsection{Library programmes}

Out of 118 , only one (1\%) rural school respondent indicated that his or her school provides library programmes. In the urban category, out of 45 , only two (4\%) respondents indicated that they offer library programmes. This implies that the majority of the teachers and learners lack knowledge about library procedures, organisation and retrieval of information sources, library rules and policies. A timetable should be designed to allow all learners in various grades to access the library to ensure optimum usage of all resources in the collection. School library programmes should aim to promote interaction between users and media or information sources so that the stated educational aims and learning objectives are realised. Teachers should be encouraged to give learners assignments, research projects and homework, which 'will provide immediate practical application of the skills they have learned from the librarian' (Adeoti-Adekeye 1997, 590). This implies that teacher-librarians should work collaboratively with subject teachers when planning tasks to be given to learners and to ensure that the necessary pertinent resources are available to enable learners to carry out given tasks or activities. Adeoti-Adekeye (ibid., 587) contends that: "A library period should be created in the school time-table for a class to be with the librarian or teacher-librarian in the library for the purpose of receiving instruction in library use.'

When asked whether or not library programmes are implemented in schools, the education officials replied as follows:

Education official A: During the few workshops we conducted, we encouraged teacherlibrarians to teach learners library programmes for them to search curriculum-related information independently. Unfortunately, there is no time. 
Education official B: Few schools with libraries may offer such programmes, but majority cannot because there are no (functional) libraries in most schools. Teacher-librarians are in classes full-time, no time for such programmes.

Education official C: Most schools lack libraries. There are no library periods in most schools to offer library related programmes, only teaching.

\subsection{Outreach programmes and competitions}

From Table 3, only four out of 118 respondents from the rural category indicated that their schools offer outreach programmes and competitions. Out of 45, no urban school respondent replied to the question. It is well-documented that school and public or community libraries can work together to encourage learners to have competitions (DBE 2012). The aim should be to encourage learners to use as many library-based resources as possible to inspire the acquisition and imparting of specific skills in them. When asked whether or not schools take part in outreach programmes, education officials responded as follows:

Education official A: We encourage schools to participate in outreach programmes and competitions for the benefit of the learners. The Unit cannot organise competitions and outreach programmes due to lack of budget.

Education official B: Schools are encouraged to take part in outreach programmes for learners' sake. We cannot organise competitions for schools due to lack of budget.

Education official C: There is lack of manpower in the School Library Unit. We are only three officials responsible for all primary and high schools in the province. This is a tedious job.

Concerning the outreach programmes and competitions, in historically disadvantaged rural communities, schools should take initiative on their own due to obvious scarcity of public or community libraries.

\subsection{Celebrations of library calendar days}

Teacher-librarians, in collaboration with subject teachers, should plan in advance how to celebrate special library days by compiling a library calendar of events. This information should be distributed to all relevant stakeholders in the school. However, out of 163 , only nine $(6 \%)$ respondents indicated that their schools celebrate library calendar days. Learners and teachers are supposed to know that on such days they will be commemorating or celebrating calendar days such as South Africa Library Week, World Book Day, Mother-Tongue Day, Readathon and World Aids Day. The aim is to encourage the users to use library resources to get information and acquire knowledge (DBE 2012). A total of 104 (63\%) respondents did not respond indicating 
that due to lack of well-resourced and staffed purpose built school libraries, schools are unable to offer such programmes and services.

When asked whether or not their schools specifically celebrated the Readathon or Literacy Month, the respondents replied as indicated in Figure 1:

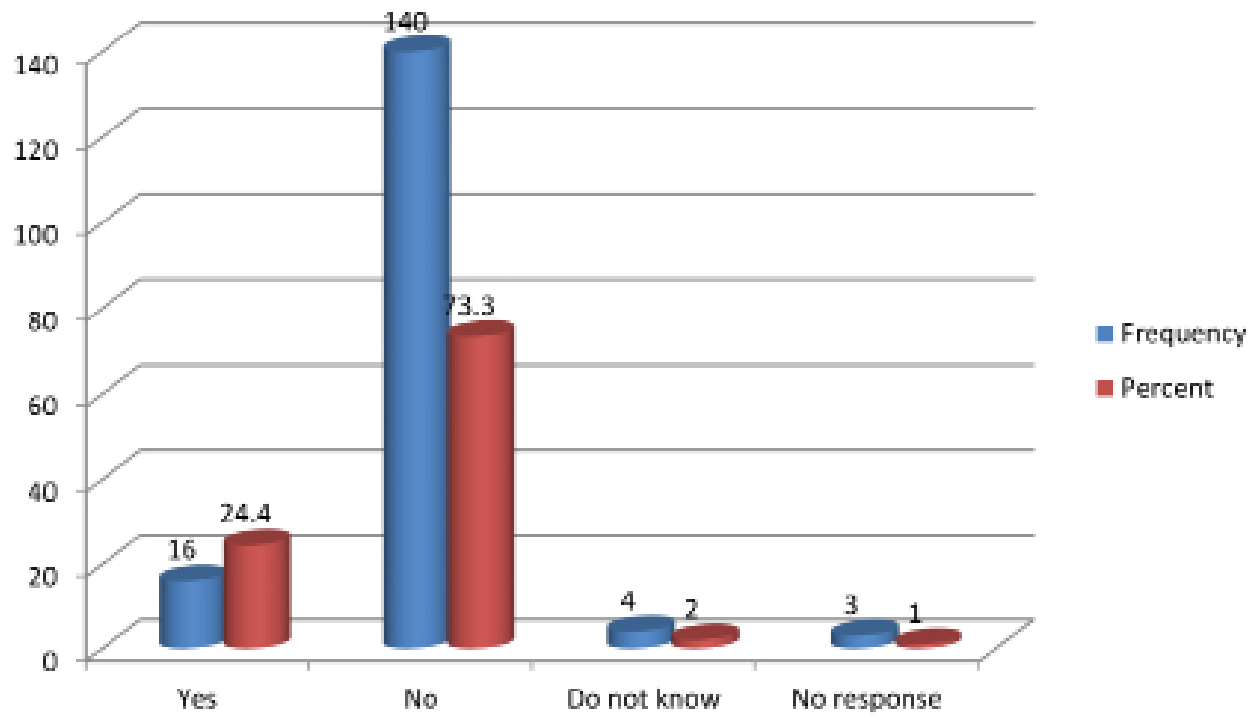

Figure 1: Readathon celebrations

Out of $163,140(73 \%)$ of the respondents jointly gave negative responses. The percentage was higher than 50 per cent, which means that the majority of the schools did not celebrate the Readathon in their schools. Only $16(9 \%)$ of the respondents cumulatively yielded positive responses indicating that very few schools celebrate the Readathon. Out of 163, only four ( $2 \%$ ) respondents opted for 'DO NOT KNOW', while three $(1 \%)$ respondents cumulatively did not respond. When asked whether or not the DBE supports the celebration of Readathon, the education officials replied as follows:

Education official A: We encourage schools to celebrate Literacy Month in September annually. Without budget, there is nothing we can do.

Education official B: We issue a circular to make schools aware of the Readathon celebrations. We used to send brochures and flyers to schools to encourage Readathon celebrations, however, due to lack of budget now, we cannot.

Education official C: Schools choose their days to celebrate Readathon in September annually.

The respondents who responded negatively were asked to indicate how they made learners aware of the Readathon. They cited the following: Out of 140 , eight $(6 \%)$ 
respondents collectively pointed out that they were not aware of the dates of these celebrations. Only one (1\%) of the respondents stated that only primary schools were celebrating Readathon. Two (1\%) of the respondents pointed out that only language teachers were responsible for making learners aware of the importance of reading. Eight $(6 \%)$ of the respondents indicated that their schools became aware of literacy celebrations when they saw the Readathon posters, pamphlets and flyers. Only two $(1 \%)$ of the respondents indicated that they do not celebrate the Readathon because they did not have time as they were involved in full-time teaching. Eleven $(8 \%)$ of the respondents indicated that subject teachers explained the importance of reading in assemblies and classes.

Only $13(9 \%)$ of the respondents mentioned that nothing was done regarding Readathon celebrations at their schools, they only teach. One (1\%) of the respondents commented 'no library, no celebrations'. One (1\%) of the respondents commented that the DBE notified his or her school through a circular or memorandum, while one $(1 \%)$ of the respondents indicated that his or her school selected its own week to celebrate Readathon. Out of 140 cumulatively, 95 (68\%) of the respondents did not reply to the question.

\section{SUMMARY}

School libraries are important resource centres to support effective teaching and learning accomplishments world-wide. They also exist particularly for the implementation of the well-designed and well-articulated library programmes and services to support education irrespective of the paradigm.

\section{CONCLUSION}

The study concludes that owing to dysfunctional school facilities in the majority of the schools in Limpopo province, only a tiny minority of the public schools offer library programmes and services. It implies that the majority of the learners in particular lack reading skills and information literacy skills which are rudiments for lifelong and independent studies. Without exposure to wide-ranging information sources, it is a challenge for learners to develop reading skills and habits which may culminate in reading culture. The non-existence of well-resourced and staffed school libraries with well-designed and spelt-out library programmes and services in the majority of the schools is a stumbling block for learners and teachers to effectively develop and acquire information literacy skills to search information on their own.

\section{RECOMMENDATIONS}

The study recommends that school-based library programmes and services should be infused in the curriculum to give teachers and learners a platform for the acquisition 
of the media and literacy skills which form the basis of life-long learning and independent studies. An approved and legislated school library policy with clearly defined library programmes is indispensable to direct and guide teachers, teacherlibrarians and other relevant stakeholders to successfully implement them. The study recommends that reading promotion programmes should be established by the DBE in collaboration with NGOs, such as Room to Read, Biblionef, Read Education Trust and Community Heart, publishers and other relevant stakeholders. Schools should:

- Establish book clubs to develop and nurture reading in learners.

- Work collaboratively with public or community libraries to enable learners to take part in programmes such as Skirmish and Battle of the Books and storytelling.

- Rope in elders from local communities to assist in story-telling initiatives.

- Initiate and support outreach programmes and competitions such as reading and spelling competitions.

The study recommends that the National Guidelines for School Library and Information Services (DBE 2012) be amended [to compel and sanction the DBE to provide funding and staffing for school libraries] and converted into a legislated school library policy for the successful implementation of such library programmes and services. Schools should have a slot on the time-table to ensure that welldesigned and well-spelt-out school library programmes, activities and services are successfully implemented for the benefit of teachers and learners. Qualified, trained and dedicated teacher-librarians need to be employed in all schools for programmes and services to be successfully implemented for the benefit of teachers and learners.

\section{REFERENCES}

Adeoti-Adekeye, W. B. 1997. The need for user education in secondary school libraries. Library Review 46(8): 586-592.

Aitchison, J. 2006. Experiments in the provision of rural community libraries in South Africa: The Family Literacy Project's initiatives. Innovation 32: 94-109.

Bloch, G. 2009. The toxic mix: What's wrong with South Africa's schools and how to fix it. Cape Town: Tafelberg.

Bodlani, L. 2015. R2-billion conditional grants unspent in Limpopo as provincial departments fail to spend. http://www.dampl.co.za/.../r2-bil-conditional-grants-unspent-in-limpopo-as-pr (accessed February 19, 2016).

Chizwina, S. 2011. An exploratory study of children's reading promotion in South Africa. Mousaion 29(3): 227-247.

Collinridge, L. 2013. Schools quintile system to change? Corruption News. http://www. corruptionwatch.org.za/schools-quintile-system-to-change (accessed April 126, 2016). 
DAC see Department of Arts and Culture.

DBE see Department of Basic Education.

Department of Arts and Culture. 2013. Project report: Costing the South African Public Library and Information Services Bill. Pretoria: DAC and Cornerstone Economic Research.

Department of Arts and Culture and National Council for Library and Information Services. 2014. The Library and Information Services Transformation Charter. http://www.nlsa.ac.za/ Downloads_01/2014_Final_LIS_Transformation_Charter.pdf

Department of Basic Education. 2011. Curriculum news: Improving the quality of learning and teaching: strengthening curriculum implementation from 2010 and beyond. Pretoria: DBE.

Department of Basic Education. 2012. National guidelines for school library and information services. Pretoria: DBE.

Department of Basic Education. 2013. Annual national assessment: 2013 diagnostic report and 2014 framework for improvement. Pretoria: DBE.

Department of Basic Education. 2014. Report on the annual national assessments of 2014 Grades 1-6 and 9. Pretoria: DBE.

Department of Basic Education. 2015. South African Schools Act (No. 84 of 1996). Amended national norms and standards for school funding. www.education.gov.za/LinkClick. aspx?fileticket...tabid=188\&mid... (accessed September 17, 2015).

DSAC see Department of Sport, Arts and Culture.

Du Toit, M. and C. Stilwell. 2012. KwaZulu-Natal school library policy and its feasibility for implementation in the province. South African Journal of Libraries and Information Science 78(2): $120-131$.

Dwane, Y. 2010. No fee schools and contributions. Equal Education Magazine 1(2): 5-6.

Equal Education. 2011. We can't afford not to: Costing the provision of functional school libraries in South African public schools. Khayelitsha: Equal Education.

Giliomee, H. and L. Schlemmer. 1989. From apartheid to nation building: Contemporary South African debates. Cape Town: Oxford University Press.

Gutek, G. L. 1972. A history of the western educational experience. Prospect Heights, IL: Waveland Press.

Guthrie, G. 2011. The progressive education fallacy in developing countries: In favour of formalism. London: Springer Science \& Business Media.

Guthrie, G. 2013. Prevalence of the formalistic paradigm in African schools. Southern African Review of Education 19(1): 121-138.

Hall, K. and S. Giese. 2008/2009. Addressing quality through school fees and school funding. In South African Child Gauge 2008/2009, ed. S. Pendlebury, L. Lake and C. Cmith, 35-40. Cape Town: University of Cape Town, Children's Institute.

Hart, G. 2013. How school libraries improve literacy: Some evidence from the trenches. Mousaion 31(1): 47-60.

Hart, G. 2014. Converging paths in the drive for school libraries in democratic South Africa. http://library.ifla.org/991/1/213-hart-en.pdf (accessed July 16, 2015). 
Hart, G. and M. Nassimbeni. 2013. From borders and landscape to ecosystem: Reconfiguring library services to meet the needs of South African youth. South African Journal of Libraries and Information Science 79(1): 13-21.

Hart, G. and S. Zinn. 2007. The conundrum of school libraries in South Africa. In Libraries for the future: Progress and development of South African libraries, ed. T. Bothma, P. Underwood and P. Ngulube, 89-107. Pretoria: Library and Information Association of South Africa.

Hart, G. and S. Zinn. 2015. The drive for school libraries in South Africa: Intersections and connections. Library Trends 64(1): 19-41. https://muse.jhu.edu/journals/library_trends/ v064/64.1.hart.pdf (accessed January 26, 2016).

IFLA/UNESCO. 2015. School library guidelines. http://www.ifla.org/files/assets/school-librariesresource-centers/publications/ifla-school-library-guidelines.pdf (accessed July 19, 2015).

Kalley, J. A. 2000. Apartheid in South African libraries: The Transvaal experience. Lanham, MD: Scarecrow Press.

Keyton, J. 2011. Communication research asking questions, finding answers. 4th ed. Boston, MA: McGraw Hill.

Limpopo. Department of Basic Education. 2015. Annual survey update master [Raw data]. Polokwane: DBE.

Limpopo. Department of Sport, Arts and Culture. 2009. Draft plan 2009/10. Polokwane: DSAC.

Machet, M. P. and L. Tiemensma L. 2009. Literacy environment in support of the development of literacy skills and voluntary reading. Mousaion 27(2): 58-76.

Magara, E. and C. Batambuze. 2009. Reading promotion programmes in primary schools: A study of school library management practises in Pallisa District in Uganda. Mousaion 27(2): 108127.

Mahwasane, N. P. 2008. Provision of library services to disadvantaged children in rural areas of the Limpopo province. MInf thesis, University of South Africa, Pretoria.

Masoga, L. 2013. Polokwane 2030 smart transport vision. Speech by the Honourable MEC for Roads and Transport Lehlogonolo Masoga, Member of the Provincial Legislature, during the official launch of the Polokwane 2030 Smart Transport Vision at the Ngoako Ramatlhodi Indoor Sports Centre. www.gov.za/speech-honourable-mec-roads-and-transportlehlogonolo-... (accessed March 22, 2015).

Meier, C. 2005. The development and application of progressive education in the Netherlands and some implications for South Africa, African Education Review 2(1): 75-90.

Mojapelo, M. S. 2014. Provision of school libraries in public high schools in Limpopo province, South Africa. PhD thesis, University of South Africa, Pretoria.

Mojapelo, M. S. and L. Dube. 2014. School library development vs policy provision: Divergence or convergence? Mousaion 32(4): 1-12.

Mojapelo, M. S. and J. A. Fourie. 2014. Library and information resources in the rural schools of the Limpopo province: A small study. Mousaion 32(2): 124-149.

Motseke, M. J. 2005. OBE: Implementation problems in the black townships of South Africa. Interim: Interdisciplinary Journal 4(2): 113-121.

National Education Infrastructure Management System. 2011. National assessment report (public ordinary schools). Contract EDO305. www.education.gov.za/LinkClick. aspx?filetickettabid=358 (accessed October 10, 2012). 
National Library of South Africa. 2015. The state of libraries in South Africa. IFLA edition. Pretoria: National Library of South Africa.

NCLIS see National Council for Library and Information Services.

NEIMS see National Education Infrastructure Management System.

Ocholla, D. N. 2009. Are African libraries active participants in today's knowledge and information society? South African Journal of Libraries and Information Science 75(1): 20-27.

Paton-Ash, M. and D. Wilmot. 2015. Issues and challenges facing school libraries in selected primary schools in Gauteng province, South Africa. South African Journal of Education 35(1): $1-10$.

Payne, G. and J. Payne. 2004. Key concepts in social research. London: Sage.

Pretorius, E. J. and M. P. Machet. 2008. The impact of storybook reading on emergent literacy: Evidence from poor rural areas in KwaZulu-Natal, South Africa. Mousaion 25(2): 261-289.

Provide. 2009. A profile of the Limpopo province: Demographics, poverty, inequality and unemployment from 2000 till 2007. Provide Technical Paper Series, 2009: 1(9). Elsenburg: Provide. $\quad$ www.elsenburg.com/provide/...BP2009_1_9\%20Demographics\%20LP.pdf (accessed October 24, 2014).

Ross, R. 2005. A concise history of South Africa. Cambridge: Cambridge University Press.

Seroto, J. 2011. The provision of rural education in three provinces of South Africa since 1994: Implications for social improvement. Journal of Education Studies: Human Rights, Democracy and Social Justice in Education. Special Issue 1: 138-152.

Silbert, P. and C. Bitso. 2015. Towards functional school libraries: Supporting library assistants in under-resourced schools through a university-community-school partnership. South African Journal of Libraries and Information Science 81(1): 53-62.

Statistics South Africa. 2012. Statistical release P0301.4 Census (Revised version). http://www. statssa.gov.za/publications/populationstats.asp (accessed October 24, 2014).

Statistics South Africa. 2013. Statistical release P0318 General household survey (Revised version). http://beta2.statssa.gov.za/publications/P0318/P03182013.pdf (accessed October $25,2015)$.

StatsSA see Statistics South Africa.

Tiemensma, L. 2006. School libraries in support of voluntary reading. Innovation 33: 13-20.

Tiemensma, L. 2008. The literacy environment in support of voluntary reading: A case study in Gauteng East and the Highveld Ridge area. MInf thesis, University of South Africa, Pretoria.

Walliman, N. 2011. Research methods: The basics. New York: Routledge Taylor and Francis.

Worden, N. 2000. The making of modern South Africa: conquest, segregation and apartheid. 3rd ed. Malden, MA: Blackwell.

Zinn, S. 2006. Have trained school librarians made a difference for school libraries in South Africa? Innovation 33: 21-35. 


\section{ABOUT THE AUTHOR}

MAREDI SAMUEL MOJAPELO (PhD) is a lecturer in the Department of Information Science, University of South Africa (Unisa). He worked as a teacher in Limpopo province for 22 years. After that, he joined the Gauteng Department of Basic Education in 2008 as a Senior Education Specialist: Library Services. He also served as a member of the Limpopo province Library and Information Services Board for two terms. His main areas of interest at present are school and public or community libraries, collaborations and partnerships (ecosystems) in LIS and ICTs in education. He completed his PhD in Information Science at Unisa in 2015. 